\title{
Porównanie charakterystyk różnych wytrzymałości betonu żwirowego o zmiennym wskaźniku w/c
}

\author{
Stanisław Fic, Andrzej Szewczak \\ Katedra Budownictwa Ogólnego, Wydział Budownictwa I Architektury, Politechnika Lubelska, \\ s.fic@pollub.pl,a.szewczak@pollub.pl
}

Streszczenie: Beton, jako uniwersalny, kompozytowy materiał, jest eksploatowany w konstrukcjach pod wpływem różnych, złożonych obciążeń statycznych, dynamicznych, wpływom środowiska zewnętrznego, np. nagłe uderzenia, temperatura, wilgotność. Zapewnienie konstrukcjom betonowym bezpiecznej eksploatacji i trwałości to zadania stawiane w okresie projektowania polegające na wykonaniu badań mieszanek i próbek betonowych. Badania służą jak najdokładniejszemu odwzorowaniu pracy betonu w warunkach naturalnych z uwzględnieniem obciążeń w czasie eksploatacji.

Badania betonu w laboratorium dotyczą ustalenia wytrzymałości na ściskanie $\left(f_{c}\right)$, rozciąganie $\left(f_{c t}\right)$; w obszarze trwałości: mrozoodporności, odporności na korozję, wpływu wysokiej temperatury, nasiąkliwości. W przypadku trwałości betonu ustala się zmianę dynamicznego modułu sprężystości $E_{d}$, współczynnik intensywności naprężeń $\left(K_{I C}\right)$, lub wpływ obciążeń dynamicznych na trwałość i wytrzymałość betonu - obecnie badania te stanowią prężnie rozwijającą się grupę testów, co ma także związek z pojawianiem się nowych rodzajów cementów, kruszyw a w konsekwencji betonów nowej generacji, tj. BWW, BUWW, BSZ. Poszukuje się również możliwości modyfikacji i zwiększenia trwałości tradycyjnych betonów.

Niewątpliwie, na wszystkie w/w cechy betonu decydujący wpływ ma wskaźnik w/c, jako główny parametr strukturotwórczy definiujący układ matryca-kruszywo. W artykule przedstawiono analizę porównawczą kilku cech wytrzymałościowych betonu, w zależności od w/c (wartości 0,4-0,7). Przyjęto stałą ilość kruszywa grubego (żwiru). Analizowano wpływ wskaźnika w/c na: $f_{c}, f_{c t}, K_{I C}, E_{i}$ betonu żwirowego.

Słowa kluczowe: współczynnik w/c, wytrzymałość na uderzenie, współczynnik intensywności naprężeń.

\section{Wstęp}

W konstrukcjach betonowych i żelbetowych beton, w trakcie eksploatacji, jest bardzo często poddawany działaniom obciążeń o charakterze dynamicznym i środowiskowym $[1,2]$. Należą do nich przede wszystkim zmienne obciążenia w czasie tj. obciążenie ruchem kołowym w konstrukcjach mostowych (mosty drogowe i kolejowe) [3], obciążenie pracą i drganiami maszyn i urządzeń w fundamentach przemysłowych [4], uderzenia w pylony i filary betonowe, obciążenia środowiskowe temperaturą, różnicą ciśnień (w zbiornikach na wodę lub gaz) [5] lub budowli podziemnych [6], zmiany wilgotności betonu. Każde z tych obciążeń powoduje inny sposób zniszczenia betonu poprzez różne oddziaływanie na jego wewnętrzną strukturę. Szczególnym zagrożeniem dla bezpieczeństwa tych konstrukcji jest występowanie przypadkowych obciążeń dynamicznych przekraczających często wartość początkowo założone w projekcie, co stanowi duży problem przede wszystkim w dawniej 
wybudowanych mostach, które obecnie przystosowywane są do obecnych wymagań infrastruktury $[1,7]$. Złożony charakter tych obciążeń i ich specyfika wymagają od projektanta uwzględnienia wielu dodatkowych czynników, oprócz klasycznego obciążenia statycznego. W konsekwencji oddziaływania dynamiczne znacznie wpływają na trwałość konstrukcji betonowych i żelbetowych.

Beton jako materiał kompozytowy złożony głównie z kruszywa, matrycy cementowej i wody, z ewentualnymi dodatkami i domieszkami, charakteryzuje się innymi parametrami niż materiały bardziej jednorodne, np. stal. Proces zniszczenia oraz trwałość tego materiału zależą w dużej mierze od rodzaju samego kruszywa, przyczepności zaczynu cementowego, wskaźnika w/c, technologii wykonania, zagęszczenia i betonowania oraz ostatecznej pielęgnacji w czasie dojrzewania [8]. Uwzględnienie tych parametrów na etapie projektowania, jest trudne lub praktycznie niemożliwe, dlatego badania trwałości i wpływu czynników zewnętrznych na beton są niezwykle istotne [8].

Szczególnym zagrożeniem konstrukcji żelbetowych są nagłe uderzenia, generowane np. w trakcie uderzeń samochodów w filary mostów i wiaduktów w wypadkach drogowych. Podczas takiego uderzenia, w jednej chwili uwalniana jest bardzo duża energia (ang. Impact Energy), która może powodować zniszczenie materiału poprzez bardzo dynamiczny proces pękania betonu w miejscu uderzenia [9,10,11]. Ustalenie przebiegu i sposobu zniszczenia betonu w wyniku takiego oddziaływania zewnętrznego jest niezwykle trudne, z racji zarówno trudności w ustalenia schematu odciążenia (kierunku, wartości, wywołanej energii uderzenia) jak również niejednorodnej struktury samego betonu [12]. W efekcie obraz zniszczenia materiału jest trudny do przewidzenia, niemniej jednak należy prowadzić badania mające na celu pokazanie charakteru zniszczenia betonu. Daje to możliwość wprowadzenia do tradycyjnego etapu projektowania betonu w konstrukcjach większej wiedzy, istotnej z punktu widzenia dalszej eksploatacji obiektów obciążonych przypadkowym uderzeniem.

W artykule przedstawiono własne badania wytrzymałości betonu pod obciążeniem udarowym i porównano z innymi parametrami wytrzymałościowymi.

\section{Badania wlasne}

Do wykonania próbek betonowych użyto kruszywa żwirowego otoczakowego o frakcji 2-8 $\mathrm{mm}$ i $8-16 \mathrm{~mm} w$ proporcjach $1: 1$, pochodzące $\mathrm{z}$ kopalni $\mathrm{w}$ Gajewie (woj. Podlaskie); cementu portlandzkiego CEM I 32,5R (Ożarów) o podstawowych parametrach (tab. 1). Właściwości cementu i skład mieszanek betonowych przedstawiono w tabeli 1 i 2.

Tabela 1. Podstawowe właściwości fizyko - mechaniczne zastosowanego cementu.

\begin{tabular}{lc}
\hline Początek czasu wiązania [min] & min. 75 \\
\hline Koniec czasu wiązania & ---------- \\
\hline Wytrzymałość na ściskanie [MPa]: & \\
\hline - po 2 dniach & $\min 10$ \\
\hline - po 28 dniach & Od 32,5 do 52,5 \\
\hline Gęstość $\left[\mathrm{g} / \mathrm{cm}^{3}\right]$ & 3,05 \\
\hline Powierzchnia właściwa $\left[\mathrm{cm}^{2} / \mathrm{g}\right]$ & 3300 \\
\hline
\end{tabular}


Tabela 2. Skład mieszanek betonowych

\begin{tabular}{llcccc}
\hline Lp. & w/c & Ilość wody [1] & Ilość cementu $\left[\mathrm{kg} / \mathrm{m}^{3}\right]$ & Ilość piasku $\left[\mathrm{kg} / \mathrm{m}^{3}\right]$ & Ilość żwiru $\left[\mathrm{kg} / \mathrm{m}^{3}\right]$ \\
\hline 1 & 0,40 & 160 & 400 & 826 & 1059 \\
\hline 2 & 0,45 & 160 & 355,5 & 862 & 1059 \\
\hline 3 & 0,50 & 160 & 320 & 892 & 1059 \\
\hline 5 & 0,55 & 160 & 291 & 917 & 1059 \\
\hline
\end{tabular}

Wszystkie badania przeprowadzono po 28 dniach dojrzewania próbek w temperaturze $t=20^{\circ} \mathrm{C}\left( \pm 2^{\circ} \mathrm{C}\right)$, w otoczeniu wilgotnym (wilgotność 90\%). Wykonano badania właściwości mechanicznych - wytrzymałości na ściskanie na próbkach 6 sześciennych 150 x 150 x $150 \mathrm{~mm}$ oraz wytrzymałości na rozciąganie przez rozłupywanie (tzw. metodą brazylijską) na 6 próbkach walcowych o średnicy $150 \mathrm{~mm}$ i wysokości $300 \mathrm{~mm}$. W spółczynnik intensywności naprężeń $\left(K_{I C}\right)$ - na 3 beleczkach o wym. 700 x 150 x $70 \mathrm{~mm}$ ze szczeliną pierwotną o długości $50 \mathrm{~mm}$ i szerokości $3 \mathrm{~mm}$ obciążano w schemacie trójpunktowego zginania wg zaleceń RILEM. Wytrzymałość betonu na uderzenie (ang. Impact Strength) $\left(E_{i}\right)$ ustalono na 6 próbkach sześciennych o wymiarach 150 × 150 × 150 mm każdej serii.

W celu ustalenia wytrzymałości betonu na uderzenie zbudowano własne stanowisko badawcze - wahadłowy młot balistyczny oparty na zasadzie działania młota Green'a [18]. Szczegółowy opis stanowiska badawczego opisano w [14], natomiast na rys. 1 przedstawiono widok głównych elementów młota balistycznego.

a)

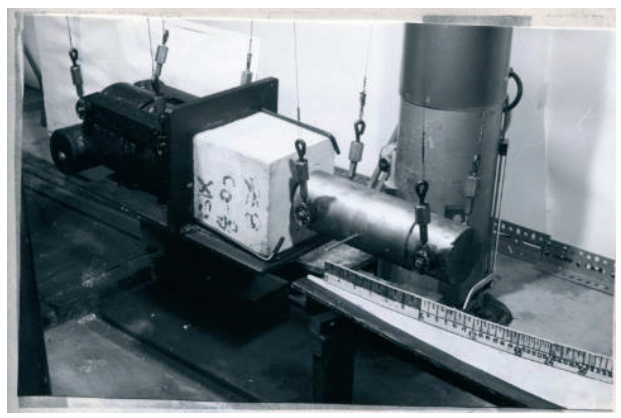

b)

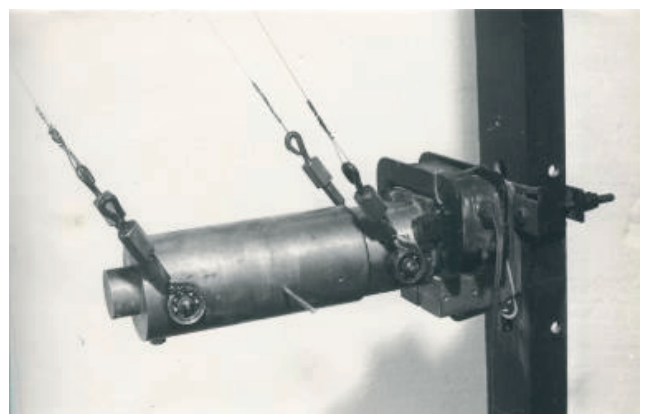

Rys. 1. Główne elementy stanowiska badawczego [18], a) kowadło z próbką betonową i bijakiem w stanie spoczynkowym, b) młot w położeniu początkowym z elektromagnesem

Na betonową próbkę, umieszczoną w przedniej części kowadła wywierano uderzenie młotem przez otwarcie obwodu elektrycznego elektromagnesu. Młot opuszczano ze stałej wysokości $h=40 \mathrm{~cm}$, czas przyłożenia obciążenia uderzeniowego wynosił 0,2-0,5 ms.

Wytrzymałość betonu na uderzenie $\left(E_{i}\right)$ zdefiniowano jako sumę energii zaabsorbowanej przez próbkę betonową do czasu jej zniszczenia po liczbie uderzeń $n$. Wprowadzony i przedstawiony w tabeli 3 współczynnik restytucji $k$, zdefiniowano jako stosunek energii odzyskanej do dostarczonej i może być dodatkową charakterystyką opisującą sprężyste i plastyczne właściwości betonu. Wielkość współczynnika $k$ dla różnych materiałów zawiera się w przedziale $0 \leq k \leq 1$. [14] Przy wartości $k=1$ materiał jest idealnie sprężysty, przy $k=0$ idealnie plastyczny. Ta skrajna sytuacja nie dotyczy jednak betonu, który posiada w mniejszym lub większym stopniu właściwości sprężysto-plastyczne, które dla zbadanych betonów przedstawiono w tabeli 3 . 
Tabela 3. Wyniki badań wytrzymałościowych, $v$ - współczynnik wariancji

\begin{tabular}{lcccccccccc}
\hline Lp. & $\mathrm{w} / \mathrm{c}$ & $\begin{array}{c}f_{c} \\
{[\mathrm{MPa}]}\end{array}$ & $v$ & $\begin{array}{c}f_{c t} \\
{[\mathrm{MPa}]}\end{array}$ & $v$ & $\begin{array}{c}E_{i} \\
{[\mathrm{Nm}]}\end{array}$ & $v$ & $k$ & $\begin{array}{c}K_{I C} \\
{\left[\mathrm{MN} / \mathrm{m}^{3 / 2}\right]}\end{array}$ & $v$ \\
\hline 1 & 0,4 & 44,2 & 5,6 & 4,63 & 8,15 & 1937,0 & 10,56 & 0,56 & 1,104 & 8,03 \\
\hline 2 & 0,45 & 38,8 & 5,2 & 3,80 & 7,65 & 1346,7 & 6,89 & 0,53 & 1,072 & 7,12 \\
\hline 3 & 0,5 & 31,6 & 5,5 & 2,93 & 6,92 & 924,8 & 8,91 & 0,50 & 1,003 & 5,81 \\
\hline 4 & 0,55 & 27,2 & 5,1 & 2,71 & 7,36 & 757,0 & 7,96 & 0,43 & 0,921 & 5,19 \\
\hline 5 & 0,7 & 17,8 & 4,3 & 1,62 & 5,18 & 231,0 & 8,33 & 0,30 & 0,715 & 4,92 \\
\hline
\end{tabular}

Liczba uderzeń $n$ do czasu zniszczenia próbki betonowej może być miara pomocniczą i w badaniach kształtowała się na poziomie 30-120 uderzeń, w zależności od w/c. Uznano jednak, że nie jest to jednostka fizyczna, i do dalszej analizy przyjęto $E_{i}$ i $k$.

Wartość $K_{I C}$ ustalono wg I modelu pękania, który charakteryzuje rozciąganie przy zginaniu. Krytyczny współczynnik intensywności naprężeń badanej belki trójpunktowo zginanej określono wg wzorów (1) i (2):

$$
K_{I C}=\sigma_{c} \sqrt{\pi a} \Upsilon(a / w)
$$

gdzie: $\Upsilon(a / w)$ - funkcja podatności uwzględniająca wymiary i kształt próbki, $\sigma_{c}-$ wielkość naprężeń w wierzchołku szczeliny:

$$
\sigma_{c}=6 M_{c} / B(W-a)^{2}
$$

$M_{c}$ - krytyczny moment zginający, $B, w, a$ - odpowiednio szerokość, wysokość przekroju próbki i długość szczeliny.

Podczas badań zastosowano szczelinomierz do pomiaru szerokości rozwarcia rys (CMOD) oraz przemieszczeń w mm. Wyniki przeprowadzonych badań własnych zestawiono w tabeli 3 .

\section{Analiza wyników badań.}

Przeprowadzone badania pokazały, że wskaźnik w/c w różnym stopniu wpływał na parametry wytrzymałościowe betonu żwirowego. Związki i zależności w/c z wytrzymałością na ściskanie $\left(f_{c}\right)$ zostały już szeroko udokumentowane w literaturze $[15,16,17]$ oraz $\mathrm{w}$ poprzednim opracowaniu.

Przykładowy przełom zniszczonej próbki przy ustaleniu $K_{I C}$ został pokazany na rys. 2 .

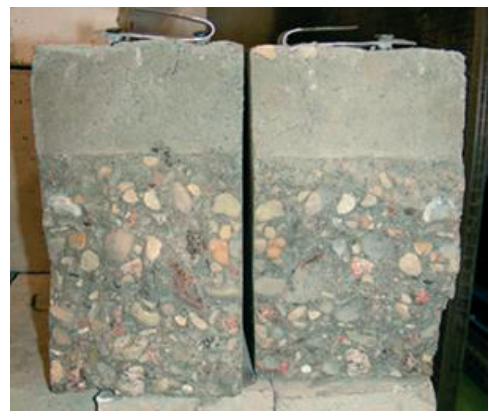

Rys. 2. Przykładowy przełom próbki przy trójpunktowym zginaniu dla $\mathrm{w} / \mathrm{c}=0,5$ 
Badania makroskopowe przełomów zniszczonych próbek przy trójpunktowym zginaniu $\left(K_{I C}\right)$ pokazały, że strefa uszkodzeń w próbkach o w/c $=0,4$ przebiegała na poziomie $30-35 \%$ zniszczonej powierzchni przez połączenie matrycy z kruszywem grubym (osłaniając ziarna), a w pozostałej części przez samą matrycę. Powierzchnia odsłoniętych przez odłupanie ziaren malała procentowo w stosunku do powierzchni przełomów zniszczenia w miarę wzrostu w/c. $\mathrm{W}$ przypadku $\mathrm{w} / \mathrm{c}=0,7$ strefa zniszczenia przebiegała praktycznie jedynie przez warstwę przejściową (ang. Interface Transmission Zone, ITZ) i w małym stopniu przez matrycę.

Obraz zniszczenia zbadanych próbek betonowych, po zakończeniu uderzeń młotem balistycznym pokazano na rys. 3 .

Przyłożenie obciążenia uderzeniowego do próbki powodowało powstanie fali naprężeń ściskających (rys. 4a), które po odbiciu od płaszczyzn próbki powracała jako fala naprężeń rozciągających, w konsekwencji niszczące element poprzez rozerwanie [14, 18]. Podczas wywierania uderzeń, w próbce ukształtował się rozrywający stożek (rys. 3 i 5).
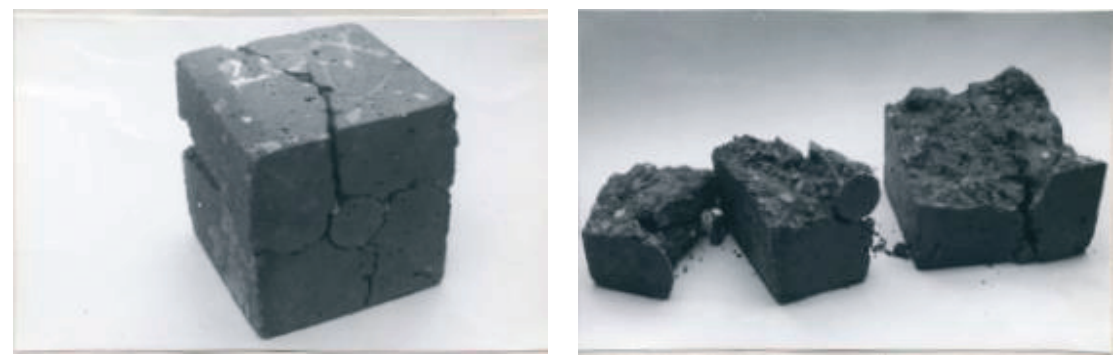

Rys. 3. Obraz zniszczenia próbki po zakończeniu uderzeń młotem balistycznym; widoczny w środkowej części próbki charakterystyczny ukształtowany stożek

a)

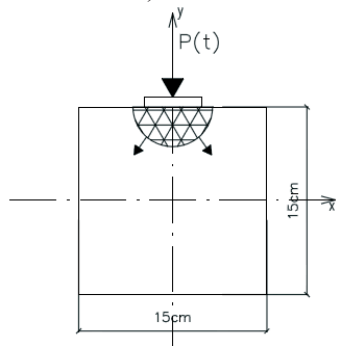

b)

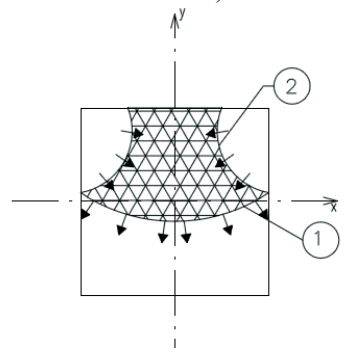

c)

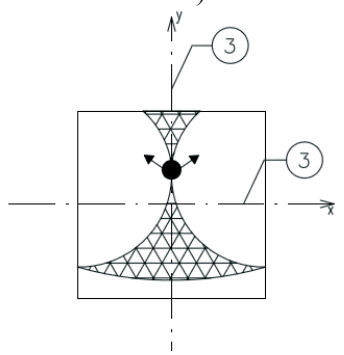

Rys. 4. a) impuls uderzeniowy i powstanie fali naprężeń ściskających, b, c) rozprzestrzenianie fali naprężeń ściskających 1, i odbitych rozciągających 2, osie zniszczenia 3

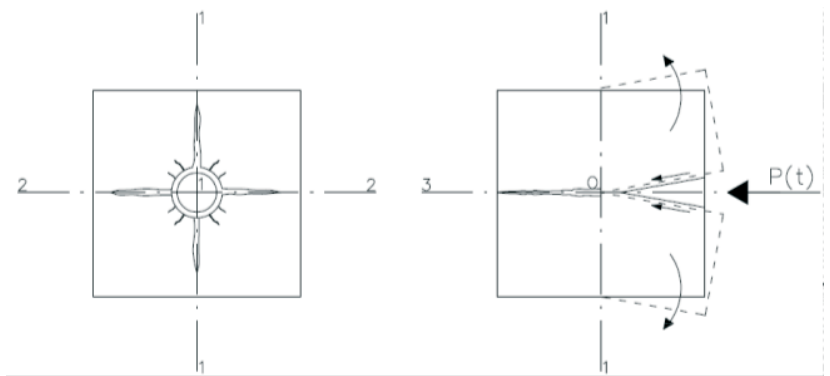

Rys. 5. Obraz tworzenia się zniszczonego stożka rozpychającego 1 - odcisk po uderzeniu bijakiem młotka, $1-1,2-2,3-3-$ osie zniszczenia próbki 
Na przełomach zniszczenia betonów o w/c $=0,4$ i 0,45 widoczne były pojedyncze ziarna przepołowione na wskroś, a strefa zniszczenia przebiegała głównie przez warstwę łączącą matrycę i kruszywo. W miarę zwiększania w/c linia zniszczenia w próbce przebiegała już przez samo połączenie matrycy z kruszywem i większości przez samą matrycę.

Procesy zniszczenia betonu uwidocznione na przełomach można prześledzić rozpatrując poniższe modele. Jako model wyjściowy betonu przed obciążeniem statycznym lub dynamicznym przyjęto w następujący sposób. Granica rozdziału (ITZ) pomiędzy matrycą a kruszywem związana jest z wpływem kształtu i powierzchni ziaren kruszywa. Odstęp pomiędzy poszczególnymi ziarnami kruszywa w betonach ciężkich można przyjąć jako $h=0,1 \ldots \ldots . .0,2 r$ (gdzie $r$ jest to promień ziarna). Odkształcenia i naprężenia powstają w samej matrycy a także pomiędzy matryca a ziarnami kruszywa tj. przez granicę ich połączenia ITZ. Połączenie to jako granica rozdziału ITZ w materiale kształtuje się w procesie wiązania i twardnienia spoiwa. Wiadomo, że w procesie twardnienia zachodzą zmiany objętościowe materiału, głównie związane ze skurczem. Kształtowanie układu odkształcenia - naprężenia w matrycy zależy od adhezyjno - kohezyjnych sił połączeń na granicach z ziarnami kruszywa. Można wydzielić 3 charakterystyczne sytuacje kształtowania granicy rozdziału. (ITZ) [12,19], przyjmując jako wyjściowy wycinek z fragmentu objętości betonu (rys. 5).

- adhezja matrycy skierowana do powierzchni ziarna kruszywa $R_{A}$ większa od sił kohezji $R_{K}\left(R_{A}>R_{K}\right)$,

- adhezja i kohezja są sobie równe. $R_{A}=R_{K}$,

- adhezja jest mniejsza od kohezji. $R_{A}<R_{K}$.

Dla warunku $R_{A}>R_{K}$ granica rozdziału powstaje praktycznie od razu po stwardnieniu struktury i nie ulega większym zmianom w czasie. W matrycy powstają odkształcenia i naprężenia rozciągające co prowadzi do powstania uszkodzeń jako rysy pomiędzy ziarnami kruszywa (rys. 6). Dla warunku $R_{A}=R_{K}$ następuje rozdzielenie odkształceń skurczowych w matrycy. Gradienty odkształceń powodują powstanie odkształceń ścinających (ang. shear) i doprowadzają do naruszenia materiału w obrębie granicy rozdziału (IŻ) z kruszywem jak też w samej matrycy (rys. 7a i 7b) W tym przypadku adhezja ma charakter selektywny. Przy $\mathrm{R}_{\mathrm{A}}<R_{K}$ odkształcenia naruszają strefę połączenia matrycy z ziarnami (rys. 7c).

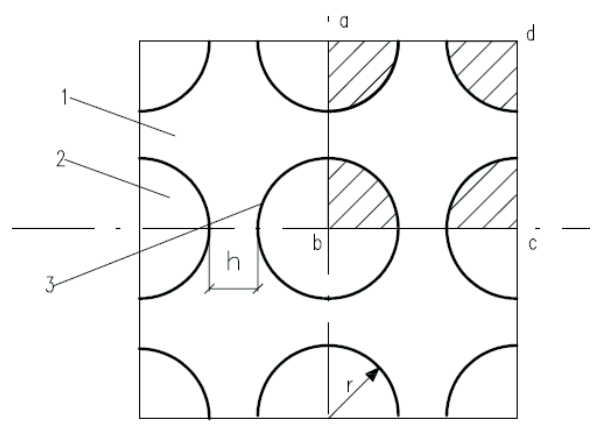

Rys. 6. Schematyczny rysunek betonu kruszywowego: 1 - matryca, 2 - ziarna kruszywa, 3 - warstwa przejściowa (połączenie matrycy z kruszywem ITZ) 
a)

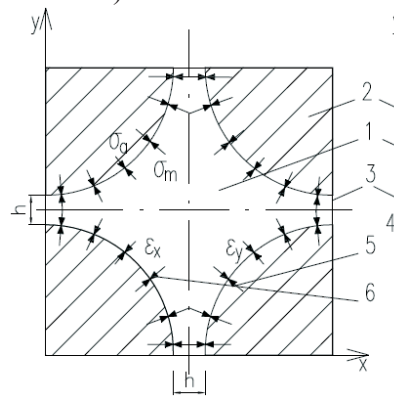

b)

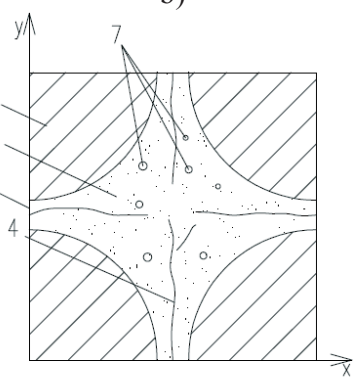

c)

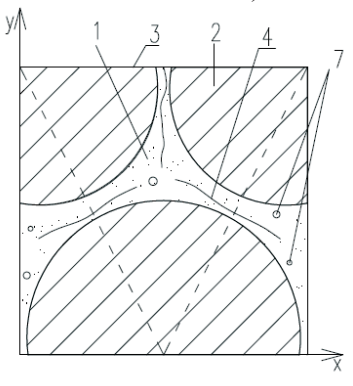

Rys. 7 Mechanizm powstawania odkształceń i rys technologicznych w betonie przy $R_{A}>R_{K}[12,19]$, a) Modelowa jednostka betonu i obraz odkształceń w jednostce modelowej betonu, b), c) Przykład ułożenia ziaren kruszywa z rysami w matrycy, 1 - matryca; 2 - ziarna kruszywa; 3 - analizowana jednostka modelowa; 4 - rysa technologiczna w matrycy; 5 - miejsce powstawania odkształceń skurczowych $\varepsilon_{x}$ i $\varepsilon_{y} ; 6$ - reakcja kruszywa $\sigma_{a}$ na obecność matrycy $\sigma_{m} ; 7$ - pory, $h=0,1 r$

a)

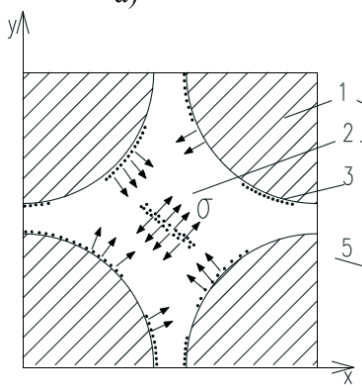

b)

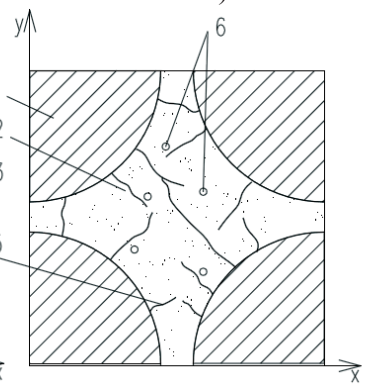

c)

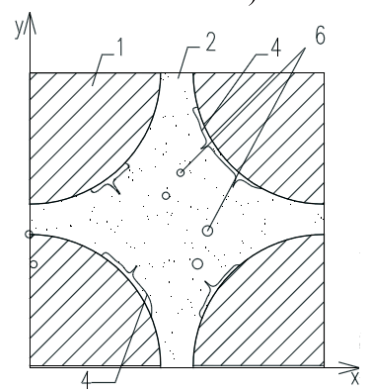

Rys. 8. Mechanizm powstawania odkształceń skurczowych i rys technologicznych w wydzielonej jednostce modelowej, a) obraz odkształcenia w jednostce modelowej, b) obraz powstałych rys przy $R_{A}=R_{K}, \mathrm{c}$ ) obraz powstałych rys przy $R_{A}<R_{K}, 1$ - ziarno kruszywa; 2 - matryca; 3 - miejsce z naruszoną adhezją; 4 - rysy technologiczne w strefie kontaktowej matryca - ziarno kruszywa; 5 - rysy promieniowe w matrycy, 6 - pory

Przyjmując model wyjściowy betonu w zależności od $R_{A}$ i $R_{K}$ (rys. 6, 7, 8) można przedstawić obraz zniszczenia powstały w betonie po uderzeniach udarowych. Na rysunkach 9, 10 i 11 pokazano schematycznie linie zniszczenia $\mathrm{w}$ betonie $\mathrm{w}$ zależności od wielkości $R_{A}$ i $R_{K}$ po zakończeniu badań przy obciążeniu udarowym.

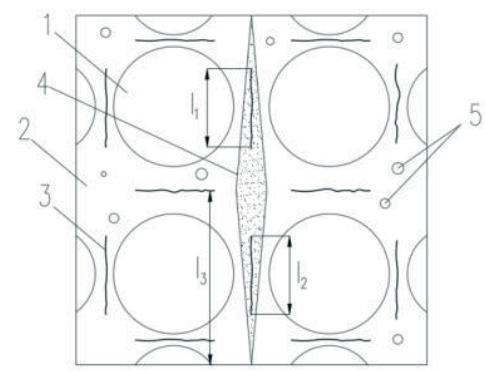

Rys. 9. Schemat powstawania rysy niszczącej po obciążeniu udarowym przy $R_{A}>R_{K}, 1$ - ziarno kruszywa; 2 - matryca; 3 - rysa technologiczna; 4 - wzrost technologicznej rysy początkowej o długości $l_{1}$ i $l_{2}$ do długości $l_{3} ; 5$ - pory 


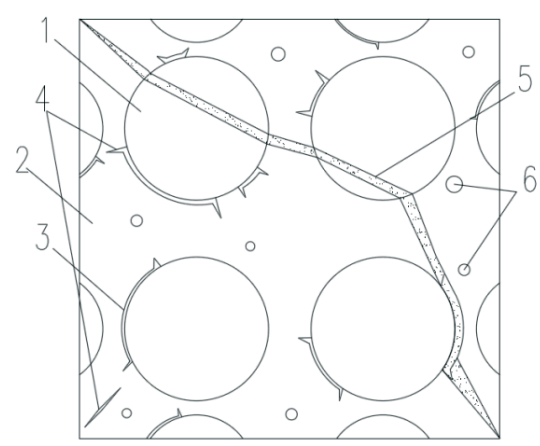

Rys. 10. Schemat powstawania rysy niszczącej przy $R_{A}=R_{K}-$ rozwój rys przez ziarna kruszywa. 1 - ziarno kruszywa, 2 - matryca, 3 - rysy w warstwie przejściowej (ITZ, 4 - rysy w matrycy, 5 - rysa powstała po wywieraniu uderzeń, 6 - pory

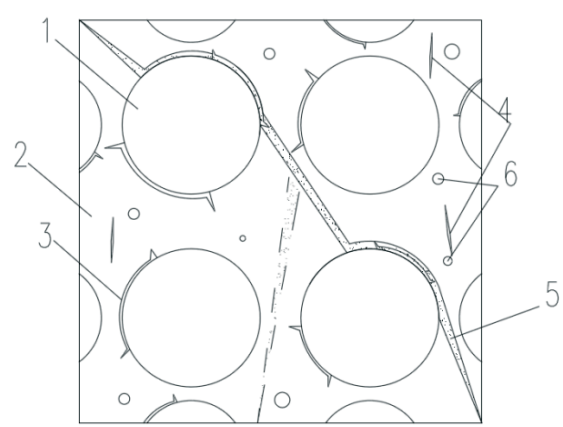

Rys. 11. Schemat powstawania rys po obciążeniu udarowym przy $R_{A}=R_{K}$ - rozwój rys przez matrycę i warstwę przejściową ITZ matrycy,1 - ziarno kruszywa; 2 - matryca; 3 - rysy technologiczne w warstwie przejściowej ITZ; 4 - rysy technologiczne w matrycy; 5 - rysa powstała po wywieraniu uderzeń, 6 - pory

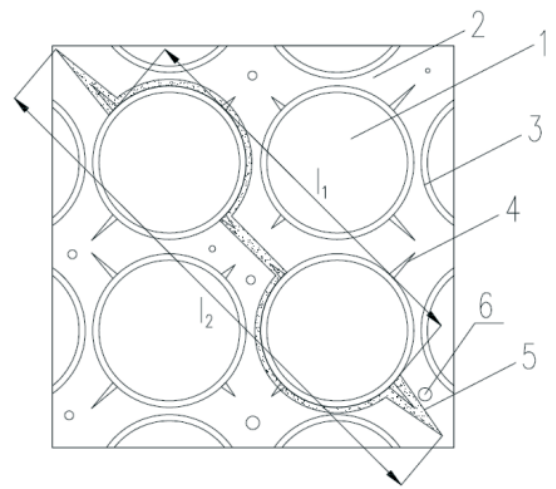

Rys. 12. Schemat powstawania rys po obciążeniu udarowym przy $R_{A}<R_{K}$ - rozwój rys przez matrycę i warstwę przejściową, 1 - ziarno kruszywa; 2 - matryca; 3 - warstwa połączeniowa ITZ; 4 - rysy technologiczne $11 ; 5$ - rysa niszcząca powstała po wywieraniu obciążeń udarowych o długości 12,6 - pory

W tabeli 4 przedstawiono procentową zmianę różnych parametrów wytrzymałościowych betonu w zależności od w/c. 
Tabela 4. Procentowa zmiana badanych parametrów wytrzymałościowych w zależności od w/c, (wartość $\mathrm{w} / \mathrm{c}=0,4$ przyjęto jako $100 \%)$

\begin{tabular}{ccccccc}
\hline $\mathrm{w} / \mathrm{c}$ & $f_{c}$ & $f_{t}$ & $E_{d}$ & $E_{s}$ & $k$ & $K_{I C}$ \\
\hline 0,4 & 100 & 100 & 100 & 100 & 100 & 100 \\
\hline 0,45 & 87,8 & 82,1 & 82,6 & 69,5 & 94,6 & 97,1 \\
\hline 0,5 & 71,5 & 63,3 & 66,3 & 47,7 & 89,3 & 90,80 \\
\hline 0,55 & 61,5 & 58,3 & 58,7 & 39,1 & 76,8 & 83,4 \\
\hline 0,7 & 40,3 & 35 & 39,3 & 11,92 & 53,6 & 64,8 \\
\hline
\end{tabular}

\section{Podsumowanie}

W zaproponowanym modelu betonu (rys.7 i 8) można wydzielić rysy technologiczne (RT). Przyjęto definicję, że rysami technologicznymi będą defekty strukturalne powstałe W objętości betonu w procesie twardnienia i obróbki materiału i są obecne do czasu przyłożenia obciążeń. Przykład powstałych rys technologicznych na styku ziarna kruszywa i matrycy pokazano na rys. 13 i 14 . Powstanie rys technologicznych związane jest zatem z samoorganizacją czyli samorzutnym procesem powstawania ustabilizowanych struktur bez wpływów zewnętrznych. Tak więc, przedstawione na modelach (rys. 7 i 8) defekty można zakwalifikować jako rysy technologiczne.
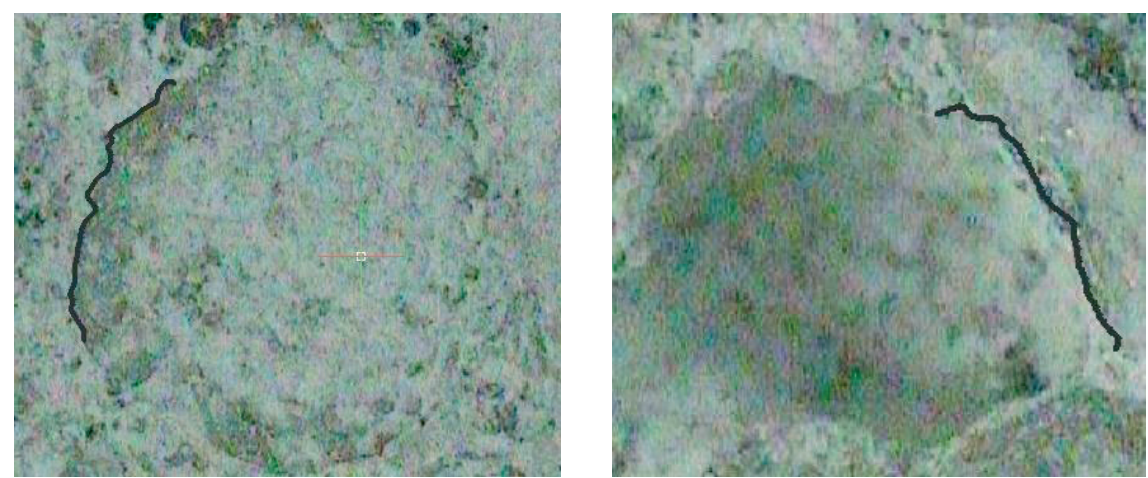

Rys. 13. Obraz struktury betonu $\mathrm{z}$ widocznymi rysami technologicznymi na styku ziarna kruszywa i matrycy

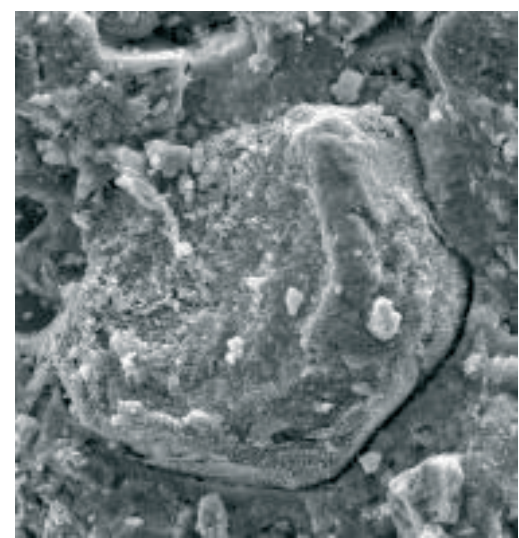

Rys. 14. Rysa technologiczna w zaczynie cementowym po 28 dniach (SEM X 1000) 
W przypadku zniszczenia betonu pod wpływem wywieranych uderzeń udarowych, czoło fali uderzeniowej zmienia swoją prędkość i energię przy przejściu przez matrycę, warstwę przejściową ITZ i ziarna kruszywa. Takie zjawisko ma wpływ na powstawanie odkształceń, co związane jest także $\mathrm{z}$ różnymi właściwościami materiałów $\mathrm{w}$ samym betonie. $\mathrm{W}$ taki sposób również rysy technologiczne stają się głównym miejscem, w którym powstałe odkształcenia na brzegach rys mogą wzmacniać i rozdzielać energię powodując w ten sposób ich wzrost $\mathrm{i}$ ich rozwój rys u ich ujścia. Rysy technologiczne po sukcesywnym wywieraniu uderzeń przekształcają się i łączą z innymi tworząc linie zniszczenia w materiale $[8,9,12,14]$. Powtarzające się cykle wywierania uderzeń powodują ciągłe dostarczanie energii zwiększając poziom destrukcji w materiale.

Kinetyka wzrostu rys do rys niszczących zależy nie tylko od liczby cykli uderzeń ale także od charakteru rozkładu rys technologicznych w materiale. Szybki wzrost rys technologicznych w niszczące następuje przy $R_{A}>R_{K}$ już przy małej liczbie uderzeń. Obraz takiego zniszczenia pokazano modelowo na rys.9. Przy adhezji $R_{A}=R_{K}$ rysy technologiczne zmieniają się w rysy niszczące zarówno przechodzące przez matryce jak i przez ziarna kruszywa. W przypadku $R_{A}<R_{K}$ przyłożenie obciążenia udarowego do utworzonych rys technologicznych, głównie w warstwie przejściowej ITZ, obserwuje się na przełomach ich rozwój wokół obwodu ziaren kruszywa a następnie przejście przez matrycę do ziaren sąsiednich. (rys. 12). Przełomy zniszczenia próbek betonowych przy trójosiowym zniszczeniu (badanie $K_{I C}$ ) charakteryzowały się pojedynczą magistralą niszczącą próbkę powstałą przez wymuszenie istniejącym nacięciem. Podobnie jak w przypadku uderzeń udarowych można wyróżnić 3 przypadki: $\left(R_{A}>R_{K}, R_{A}=R_{K}, R_{A}<R_{K}\right)$.

\section{Wnioski}

Przeprowadzone badania pokazały istotną różnicę wpływu w/c na $E_{i}, f_{c}, f_{c t}, K_{I C}$. Zwiększenie wskaźnika w/c z wartości 0,4 do 0,7, a tym samym zwiększenie ilości defektów strukturalnych (pory, kapilary, rysy technologiczne) wpłynęły najbardziej na obniżenie $E_{i}$ (tab. 4), w następnej kolejności na $f_{c t}, f_{c}$, i $K_{I C}$. W badaniach wykazano, że wytrzymałość na uderzenie jest najbliższa $f_{c t}$, co potwierdzono procentowym obniżeniem tych parametrów. Obraz przełomów próbek pokazał, oddziaływanie uderzeń spowodowało przebieg centralnej magistrali zniszczenia przez ITZ i w mniejszym stopniu przez matrycę. Wskazuje to na większy wpływ adhezji w połączeniach ziarno-kruszywo-matryca na $E_{i}$ w porównaniu $\mathrm{z} f_{c t}, f_{c}$ i $K_{I C}$.

Badania zostały sfinansowane ze środków statutowych Katedry Budownictwa Ogólnego SB/14/16.

\section{Literatura}

1. Jamroży Z., Beton i jego technologie, wyd. 4, PWN, Warszawa, 2015.

2. Ślusarek J., Problemy trwałości wybranych konstrukcji betonowych, wyd. Politechniki Śląskiej, Gliwice, 2008.

3. Karaś S., Słowik M., Distribution of Reinforcement in Tensile Flanges of Concrete T-shape Continuous Beam, Journal of Civil Engineering and Architecture 4(11) (2010) 59-64.

4. Dzierżanowski A., Szymaniec S., Drgania napędów elektrycznych, fundamentów, konstrukcji wsporczych oraz budynków przemysłowych, Wiadomości Elektrotechniczne 4 (2000) 190-193.

5. Krętowski J., Tribiłło R., Wpływ obciązenia temperaturowego na stan odksztatceń płyty przekrywajacej zbiornik wypetniony ciekłym medium, Przegląd Budowlany 81(9) (2010) 34-38. 
6. Duży S., Dyduch G., Wpływ czynników środowiskowych na zużycie techniczne konstrukcji obudowy budowli podziemnych, Górnictwo i Geologia 5(2) (2010) 37-46.

7. Jankowiak T., Kryteria zniszczenia betonu poddanego obciażeniom quasi - statycznym i dynamicznym, rozprawa doktorska, Wyd. Politechniki Poznańskiej, Poznań, 2011.

8. Shradar E.K., Impact resistance and test procedure for concrete, ACI 78(2) (1981) 141-146.

9. Cantwell W.J., Morton J., The Impact resistance of composite materials, Composites 22(5) (1991) 347-362.

10. Song P.S., Wu J.C., Hwong S., Shen B.C. Statistical analysis of impact strength reliability of steel - polypropylene hybrid fiber - reinforced concrete, Construction and Building Materials 19(1) (2005) 1-9.

11. Krajenovic D., Silva M.A.G., Analysis of tests on impact strength of concrete armor blocks, Journal of Impact Eng. 2(4) (1984) 331-343.

12. Fic S., Nikolayevych V., Dorofeev V.S., Procesy samoorganizacji struktury kompozytowych materiatów budowlanych, Lublin University of Technology, Lublin, 2013.

13. Kolluru S, Popovics J., Sahah S., Determining elastic properties of concrete using vibrational resonance frequencies of standard test cylinder, Cem. Concrete and Aggregate 22(2) (2000) 81-89.

14. Fic S. Beton pri udarom magrużkie, Odessa 2004, p.30.

15. Neville A.M., Properties of concrete, London 2010.

16. Shradar E.K., Impact resistance and test procedure for concrete, ACI 78(2) (1981) 141-146.

17. Brandt A.M., Prokopski G., On the fractal dimensions of fracture surfaces of concrete elements, J. Mater. Sci. 28 (1993) 4762-4766.

18. Hughes B.P., Gregory R., The impact strength of concrete using Green's ballistic pendulum, Proc. Inst. Of Civil Eng. 41. London, 1968.

19. Vyrovoy V.N., Dorofeev S., Suhanov V.G., Kompozicionnye stroitelne materialy i konstrukcji, Odessa 2010 p. 68.

\title{
Comparison of different strength characteristics of gravel concrete with variable index $\mathrm{w} / \mathrm{c}$
}

\author{
Stanislaw Fic, Andrzej Szewczak \\ Department of General Building, Faculty of Civil Engineering and Architecture, \\ Lublin University of Technology,s.fic@pollub.pl, a.szewczak@pollub.pl
}

\begin{abstract}
Concrete, as a universal, composite material, is used in structures under the influence of various static, dynamic loads, influences of the external environment, such as sudden impacts, temperature, humidity. Ensuring concrete constructions for safe operation and durability are tasks placed in the design phase, consisting in the testing of mixtures and concrete samples. The studies serve as the most accurate representation of concrete in natural conditions, taking into account the loads during operation.

Concrete testing in the laboratory relates to the determination of the compressive strength $\left(f_{c}\right)$, the tensile strength $\left(f_{c t}\right)$; in the area of durability: frost resistance, corrosion resistance, influence of high temperature, absorbability. In the case of concrete durability, the dynamic modulus of elasticity $E_{d}$, the stress intensity index $\left(K_{I C}\right)$, or the impact of dynamic loads on the durability and strength of concrete are determined - nowadays, they are a rapidly growing test group, which is also related to the emergence of new types of cements, aggregates and consequently new generation concrete, i.e. HSC, UHSC, HPC. Also looking for opportunities to modify and enhance the durability of traditional concrete.
\end{abstract}


Undoubtedly, for all of the aforementioned features of the concrete, the $\mathrm{w} / \mathrm{c}$ ratio is the decisive factor as the main structural parameter defining the matrix system - aggregate. The paper presents comparative analysis of several strengths of concrete, depending on w/c (values of 0.4-0.7). A fixed amount of aggregate (gravel) was assumed. The influence of the w/c ratio on: $f_{c}, f_{c t}, K_{I C}, E_{i}$ of gravel concrete was analyzed.

Keywords: w/c ratio, impact strength, stress intensity coefficient. 